\author{
BIJDRAGEN TOT DE KENNIS DER FAUNA VAN CURAÇAO. \\ Resultaten eener Reis van Dr., C. J. VAN DER HORST in 1920.
}

\title{
CIRRIPEDIA OF CURAÇAO
}

\author{
BY \\ HENRY A. PILSBRY \\ The Academy of Natural Sciences of Philadelphia. \\ (With 3 textfigures.)
}

The cirripedes of Curaçao and the southern borders of the Caribbean Sea have not been investigated hitherto. A collection of the littoral forms made by Doctor C. J. VAN DER HORST in 1920 contains the following species.

Descriptions, figures and references to other literature of the species may be found in the Monographs of DARWIN ${ }^{1}$ ) and of PILSBRY ${ }^{2}$ ).

LEPADIDAE.

Lepas anatifera Linné.

Caracas Bay.

\section{SCALPELLIDE.}

\section{Lithotrya dorsalis Sowerby.}

Caracas Bay, in Meandrina and an undetermined coral. Very perfect young specimens agreeing with DARwiN's account.

\section{Chthamalid 2 .}

Chthamalus stellatus angustitergum Pilsbry. Fig. 1. Spanish Water, on stones; abundant.

Typical specimens were taken of this form, which was originally described from the Bahamas. Probably it should be considered specifically distinct from the European C. stellatus (Poli), which it replaces in the Antillean fauna. The characteristic tergum is here drawn in outline, fig. 1.

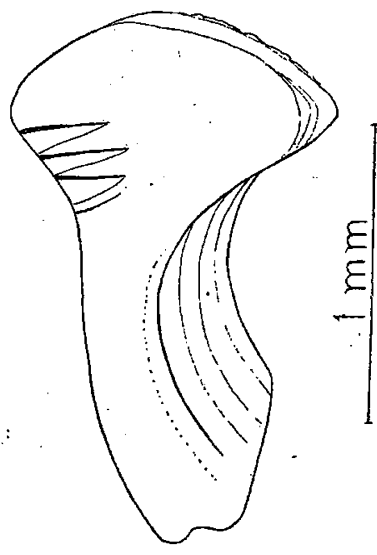

Fig. 1.

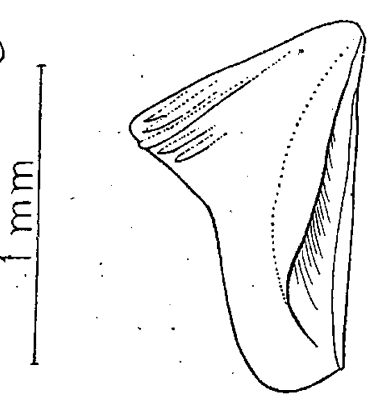

Fig. 2.

Fig. 1. Left tergum of Chthamalus stellatus angustitergum.

Fig. 2. Left tergum of Chthamalus fragilis.

Chthamalus fragilis (Darwin). Fig. 2.

Caracas Bay; detached specimens from some smooth substratum.

This species has not been seen heretofore from south of Jamaica. The specimens agree with the typical form in the characters of the cirri, the second cirrus having a group of serrate spines; but it differs by

1) Monograph on the Subclass Cirripedia: The Lepadidæ. 1851.

2) Sessile Barnacles contained in the collection of the United States National Museum, with a Monograph of the American species. Bull. U. S. Nat. Mus. 93. 1916. 
the more lengthened and slender basal part of the tergum, as seen in fig. 2. In northern specimens the tergum is very short, as shown in my monograph, p. 300, fig. $83 a, d$, from Ocean City, New Jersey. In those from further south it is of intermediate contour, as in my pl. 70, figs. $1 d, 3 a$. Finally, in the Caracas Bay specimens it is longer than in any others examined. The scutum, in these specimens, agrees with my pl: 70 , fig. $1 c$, being of typical form.

\section{BALANIDE.}

Balanus tintinnabulum antillensis Pilsbry. Fig. 3.

Caracas Bay, on a bouy; also on Millepora alcicornis (Linné).

Specimens typical in color, form, and external sculpture of the walls, as well as in the opercular valves, were taken on a bouy. One which I cut has 24 tubes in the lateral compartment. Two of the type lot of $B$. $t$. antillensis from St. Thomas have 14 and 15 tubes in the same compartment, while typical $B$. tintinnabulum has between 50 and 60 .
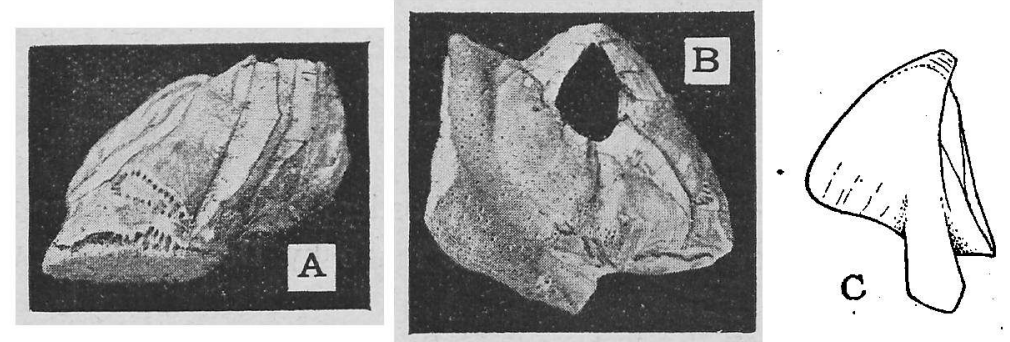

Fig. 3. A, B, Balanus t. antillensis on Millepora $\times 1$. C, tergum of same individual $\times 3$.

The specimen illustrated in fig. 3 grew upon a millepore, and was enveloped by it except for the orifice, in the manner of Pyrgoma. The layer removed from the walls of the barnacle figured was about 1 to $2 \mathrm{~mm}$. thick. The walls are white except for a faint trace of rose tint in one place on the lateral compartment. The parietes are slightly roughened but not in the least ribbed. The lateral compartment has only 11 tubes. The rostro-carinal diameter is $24 \mathrm{~mm}$, height $15 \mathrm{~mm}$. The scutum has the basal margin and the growth riblets more sinuous than usual in this race. The spur of the tergum is hardly more than its own width from the basi-scutal angle. (Fig. $3 \mathrm{C}$ ).

The labrum has a small tooth on each side of the median notch. The first cirrus has 23 and 17 segments, the second 17 and 13, and the third 14 and 11 segments. Later cirri have spines arranged as in typical $B$. tintinnabulum, but there are no minute spinules along the distal borders of the segments, the individual segments being longer.

\section{Balantıs galeatus (Linné).}

Caracas Bay, on a gorgonian.

In these examples the contour is oval, the end compartments not in the least lengthened, and the basis is flat. Size small, about $5 \mathrm{~mm}$. in rostro-carinal diameter. The opercular valves are typical in form.

Tetraclita stalactifera (Lamarck).

Spaansche Haven. Caracas Bay, on stones.

Typical examples.

Tetraclita radiata Blainville.

Caracas Bay, growing on Balanus tintinnabulum antillensis from a bouy, and on Millepora alcicornis.

Some individuals were enveloped up to the orifice by the millepore, as described above for Balanus tintinnabulum antillensis. 